\title{
Association between duration of residence with gingival pigmentation in Nuha District, East Luwu Regency, South Sulawesi, Indonesia
}

\author{
Rasmidar Samad, ${ }^{1 *}$ Qushay U. Malinta ${ }^{2}$
}

\section{Abstract}

Objective: Gingival Pigmentation (GP) is change of gingival color caused by deposition of pigment or other tissue-colorizing substances. Normal color of gingival tissue sometimes termed "coral pink" or "salmon pink". The change of gingival color from brownish to black could result in medical and/or aesthetical problems. This study proposed to determine the association between duration of residence with gingival pigmentation to the community of Nuha District of East Luwu society. This study as a descriptive observational with crosssectional study design.

Material and Methods: The population in this study was all of the Nuha residents. The sampling technique used was simple. Gingival pigmentation in this study was measured using Dummet Oral Pigmentation Index (DOPI).

Results: The data obtained showed significant association between duration of residence with maxillar and mandibular gingival pigmentation in the residents of Nuha District of Luwu Timur. p-value for maxillar DOPI was 0.003 and for mandibular DOPI was 0.000 .

Conclusion: Duration of residence in a Nuha District, Luwu Timur Regency, South Sulawesi shows significant association with severity of gingival pigmentation among the residents. Such duration that represents the duration of exposure and accumulated amount of exposure.

Keywords: Duration of residence, Gingival pigmentation

Cite this Article: Samad R, Malinta, QU. 2017. Association between duration of residence with gingival pigmentation in Nuha District, East Luwu Regency, South Sulawesi, Indonesia. Journal of Dentomaxillofacial Science 2(1): 18-22. D0I:10.15562/jdmfs.v2i1.451

'Department of Public Health Dentistry, Faculty of Dentistry, Hasanuddin University, Makassar, Indonesia

${ }^{2}$ Department of Physiology, Faculty of Medicine, Hasanuddin University, Makassar, Indonesia

${ }^{*}$ Correspondence to: Rasmidar Samad, Department of Public Health Dentistry, Faculty of Dentistry, Hasanuddin University hscrp.samad@gmail.com

Received 27 November 2016 Revised 03 December 2016 Accepted 03 January 2017 Available online 01 April 2017

\section{Introduction}

Gingival Pigmentation (GP) is change of gingival color caused by deposition of pigment or other tissue-colorizing substances. Normal color of gingival tissue sometimes termed "coral pink" or "salmon pink". The change of gingival color from brownish to black could result in medical and/or aesthetical problems. Patients often complain about darkened gingival mucosa. Such complains may have varying degrees and may result from physiological or pathological process from either endogenous factors, exogenous or both. ${ }^{1,2}$

One of the endogenous factors of GP is increased melanin production by melanocyte-dendtitic cells in basal epithelial tissue. ${ }^{3}$ In the other hand, exogenous factor of GP is related to incorporation of foreign substances into the tissue. Sources of these external substances may be the result of some behavior, such as gingival tattoo, medication and smoking, etc. ${ }^{1}$

Heavy metal exposure such as lead, bismuth, mercury, silver arsenic and gold, can be detected from elevated blood concentration and has also been known as the cause of discoloration of oral mucosa. ${ }^{4}$ Elevated heavy metal concentration in the water, air and food sources causes significant effect on human health. ${ }^{5}$ Exposure can be detected in several organs in the body, including tissues such as teeth, periodontal, lips, tongue, mucosal membrane, salivary gland and alveolar bone. ${ }^{6}$

In South Sulawesi Province, Luwu Timur Regency is one of many lands that have high concentration of naturally occurring heavy metals that attracts mining corporations. Previously extracted lands are often re-vegetated into agricultural sections. ${ }^{7}$ In spite of the good intention, these re-vegetation practices have been detrimental to the plants and animal living in the area since they are exposed to water and soil that has high heavy metal concentration.

Previous studies conducted in Luwu Timur Regency, specifically in Nuha District, has shown that heavy metal concentration is higher that acceptable limit in the grass that grows in the ex mines. When livestock living in that area are fed with such grass, the heavy metals may accumulate in their meat over time. ${ }^{8}$ Since humans also lives and consumes agricultural products from these lands, they are also prone to elevated concentration of heavy metal in their body.

Although physiological pigmentation may occur in the human body due to increased melanin production, external, non-physiological factors such as heavy metal absorption may precipitate in the vascular and sub-epithelial tissue.,10 
Heavy metal exposures on the oral tissue have been observed to have accumulative effect. ${ }^{11}$ Hence, this present study was designed and conducted to determine the association of gingival pigmentation as a sign heavy metal exposure to duration of residence in people living in land containing high heavy metal level, such as the Nuha District, Luwu Timur Regency, South Sulawesi.

\section{Material and Methods}

This descriptive, observational study with crosssectional design has been conducted in Nuha District, Luwu Timur Regency from September 30 - October 2, 2014. Among five villages in Nuha District, three villages were chosen from random-ization. The selected villages were Sorowako, Nikkel and Magani. Population of the subject wasall of Nuha District residents which were sampled with two stage, simple cluster sampling. The number of subjects was 100 which was calculatedusing slovin formula:

$$
\begin{aligned}
\mathrm{n} & =\frac{\mathrm{N}}{1+\mathrm{N} \alpha^{2}} \\
& =\frac{23.429}{1+\left(23.429 * 0,1^{2}\right)} \\
& =99,58
\end{aligned}
$$

Legend:

$\mathrm{n}$ : number of sample subjects

$\mathrm{N}$ : number of population

e: error tolerance (\%)

\section{Inclusion and exclusion criteria}

Inclusion criteria for the subjects were Nuha District residences of aged 12 years or older. Exclusion criteria were:

- Subjects that have smoking habit or had been having smoking habit

- Subjects that are or were in long term antibiotics medication

- Subjects that are or were using oral contraceptives

- Subjects that refuses to participate in the study

\section{Operational definitions of the variables}

Measured variables in this study were gingival pigmentation and duration of residence in Nuha District. Gingival pigmentation was measured as ordinal value and duration of residence was measured as nominal value.

- Causative variable:

Duration of residence was defined as the length of time spent living in Nuha District until the time of study. This variable was measured in years.

- Effect variable:

Gingival pigmentation was defined as change of normal gingival color. Based on DummetGupta Oral Pigmentation Index (DOPI), the discoloration ranges from light brown to bluish black. This range is quantified to allow categorization of its severity.

\section{Assessment criteria}

There are several variables that were measured with each of their assessment criteria.

\section{- Gingival pigmentation}

Gingival pigmentation was clinically assessed using dental mirror and the severity was assessed according to DOPI into several categories, such as mild, moderate and severe pigmentation. In either maxilla or mandible, was divided into 32 spatial units (16 units in palatal/lingual aspect, and 16 other in buccal/labial aspect). Each units is localized in their respective gingival area that extends from apical aspect for about 4-5 $\mathrm{mm}$ to gingival attachment. In the case of partial or total edentulous, these spatial units can still be used to assess the gingival since the assessment is independent of the presence of tooth. ${ }^{2}$

To allow categorization and quantification, each of the 32 units is assessed for pigmentation based on the scale below:

$0=$ gingival color is
pink $\rightarrow \begin{aligned} & \text { no clinical } \\ & \text { pigmentation }\end{aligned}$

o 1 = gingival color is $\quad \rightarrow$ mild clinical pink-brown pigmentation

o 2 = gingival color is $\rightarrow$ moderate clinical light brown to brown pigmentation

o 3 = gingival color is $\rightarrow$ severe clinical dark brown to dark pigmentation blue

All gingival units was assessed with each of their corresponding numerical value and then summed and divided with 32. This final numbr is the DOPI. Each maxillar and mandibular DOPI are assessed independently. DOPI is categorized into:

o $\quad 0.000-0.030$ : no gingival pigmentation

o $\quad 0.031-0.970$ : mild gingival pigmentation

o $\quad 1.000-1.900$ : moderate gingival pigmentation

o $\quad 2.000-3.000$ : severe gingival pigmentation 
- Duration of residence

Duration of residence among people of Nuha District is divided into 2 categories:

\section{o Less than 10 years \\ o 10 years of more}

This categorization is according to similar study that was analyzing the effect of work condition among battery factory workers in Germany. ${ }^{11}$

\section{Type of Data and Data Analysis}

The data that were used in this study is primary data which were analyzed with Chi-square test.

\section{Results}

Table 1 shows average of gingival pigmentation expressed numerically as DOPI value based on characterization such as sex, age and duration of residence among the 100 sample subjects of Nuha District residents.

Among these samples, 89 of them $(89 \%)$ were male and $11(11 \%)$ were female. The result showed that average of DOPI among male was higher than of female. The average for the male was 0.56 with deviation standard (SD) of 0.51 for the maxilla and 0.33 with $\mathrm{SD}$ of 0.31 for mandible. For the female, the average was 0.38 with deviation standard (SD) of 0.28 for the maxilla and 0.32 with SD of 0.23 for mandible.

Tabel 1 Average of maxillar and mandibular gingival pigmentation expressed as DOPI value based on characterization such as sex, age and duration of residence

\begin{tabular}{lccc}
\hline & & \multicolumn{2}{c}{ Gingival Pigmentation (DOPI value) } \\
\cline { 3 - 4 } & & Maxilla & Mandible \\
\cline { 3 - 4 } Characteristics & & Mean \pm SD & Mean \pm SD \\
\hline Sex & $11(11.0)$ & $0.56 \pm 0.51$ & $0.33 \pm 0.31$ \\
$\quad$ Male & $89(89.0)$ & $0.38 \pm 0.28$ & $0.32 \pm 0.23$ \\
Female & & & \\
Age group & $2(2.0)$ & $0.30 \pm 0.06$ & $0.36 \pm 0.07$ \\
12-16 years old & $43(43.0)$ & $0.37 \pm 0.31$ & $0.30 \pm 0.27$ \\
17-25 years old & $49(49.0)$ & $0.41 \pm 0.33$ & $0.33 \pm 0.23$ \\
$26-35$ years old & $4(4.0)$ & $0.52 \pm 0.35$ & $0.38 \pm 0.27$ \\
$36-45$ years old & $1(1.0)$ & $0.91 \pm-$ & $0.66 \pm-$ \\
$46-55$ years old & $1(1.0)$ & $0.41 \pm-$ & $0.41 \pm-$ \\
$>65$ years old & & & $0.36 \pm 0.24$ \\
Duration of residence & & $0.44 \pm 0.32$ & $0.22 \pm 0.32$ \\
$\geq 10$ years & $72(72.0)$ & $0.29 \pm 0.29$ & \\
$<10$ years & $28(28.0)$ & & \\
\hline
\end{tabular}

Age group categorization was according to Indonesian Ministry of Health. Among 100 subjects, the group that had most subjects is 26-35 years old. The age group that had highest average of DOPI value was the $46-55$ years old, which was 0.91 for maxilla and 0.66 for mandible. Meanwhile, lowest average of DOPI value for maxilla was the 12-16 years old which was 0.30 (SD 0.06). For mandible the lowest average of DOPI value was the 17-25 years old which was 0.30 (SD 0.27).

Based on duration of residence, most subjects (72\%) have been living in Nuha District for at least 10 years. Average DOPI value for residents living at least 10 years in Nuha District was higher than of those whom had been living less than 10 years. For subjects with at least 10 years of residential duration, average of maxillar DOPI value was 0.44 (SD 0.32) and average of mandibular DOPI value was 0.36 (SD 0.24).

For subjects with less than 10 years of residential duration, average of maxillar DOPI value was 0.29 (SD 0.29) and average of mandibular DOPI value was 0.22 (SD 0.32).

Table 2 shows distribution of severity of maxillar and mandibular gingival pigmentation expressed as DOPI value based on characterization such as sex, age and duration of residence.

In the sex groups, gingival pigmentation in both male and female group was mostly mild. In the male group, most of the subjects had mild pigmentation. Six out of 11 male subjects (54.5\%) had mild maxillar pigmentation while 8 out of 11 (72.7\%) had mild mandibular pigmentation. In the female group, most of the subjects also had mild pigmentation. There were 82 out of 89 female subjects (92.1\%) had mild maxillar pigmentation and 84 out of 89 (94.4\%) had mild mandibular pigmentation.

In the age groups, gingival pigmentation assessed in both maxilla and mandible was mostly mild. In the 12-16 years old group, 2 out of 2 subjects (100\%) had mild pigmentation on both of their maxilla and mandible. In the 17-25 years old group, 39 out of 43 subjects (90.7\%) had mild pigmentation on their maxilla and 38 out of 43 subjects $(88.4 \%)$ had mild pigmentation on their mandible. In the $26-35$ years old group, 42 out of 49 subjects $(85.7 \%)$ had mild pigmentation on their maxilla and 46 out of 49 subjects $(88.4 \%)$ had mild pigmentation on their mandible. In the 36-45 years old group, 3 out of 4 subjects (75\%) had mild pigmentation on their maxilla and 4 out of 4 subjects (100\%) had mild pigmentation on their mandible. In the 46-55 years old group, there was only 1 patient and this subject had mild pigmentation on both the maxilla and mandible. 
Table 2 Average of maxillar and mandibular gingival pigmentation expressed as DOPI value based on characterization such as sex, age and duration of residence

\begin{tabular}{|c|c|c|c|c|c|c|c|c|}
\hline \multirow[b]{4}{*}{ Characteristics } & \multicolumn{8}{|c|}{ Gingival Pigmentation (DOPI value) } \\
\hline & \multicolumn{4}{|c|}{ Maxillar } & \multicolumn{4}{|c|}{ Mandibular } \\
\hline & None & Mild & Moderate & Severe & None & Mild & Moderate & Severe \\
\hline & n (\%) & n (\%) & n (\%) & n (\%) & n (\%) & n (\%) & n (\%) & n (\%) \\
\hline \multicolumn{9}{|l|}{ Sex } \\
\hline Male & $2(18.2)$ & $6(54.5)$ & $3(27.3)$ & $0(0.0)$ & $3(27.3)$ & $8(72.7)$ & $0(0.0)$ & $0(0.0)$ \\
\hline Female & $2(2.2)$ & $82(92.1)$ & $6(5.6)$ & $0(0.0)$ & $3(3.4)$ & $84(94.4)$ & $2(2.2)$ & $0(0.0)$ \\
\hline \multicolumn{9}{|l|}{ Age } \\
\hline $12-16$ y.o & $0(0.0)$ & $2(100.0)$ & $0(0.0)$ & $0(0.0)$ & $0(0.0)$ & $2(100.0)$ & $0(0.0)$ & $0(0.0)$ \\
\hline $17-25$ y.o & $1(2.3)$ & $39(90.7)$ & $3(7.0)$ & $0(0.0)$ & $3(7.0)$ & $38(88.4)$ & $2(4.7)$ & $0(0.0)$ \\
\hline $26-35$ y.o & $3(6.1)$ & $42(85.7)$ & $4(8.2)$ & $0(0.0)$ & $3(6.1)$ & $6(93.9)$ & $0(0.0)$ & $0(0.0)$ \\
\hline $36-45$ y.o & $0(0.0)$ & $3(75.0)$ & $1(25.0)$ & $0(0.0)$ & $0(0.0)$ & $4(100.0)$ & $0(0.0)$ & $0(0.0)$ \\
\hline $46-55$ y.o & $0(0.0)$ & $1(100.0)$ & $0(0.0)$ & $0(0.0)$ & $0(0.0)$ & $1(100.0)$ & $0(0.0)$ & $0(0.0)$ \\
\hline$>65$ у.о & $0(0.0)$ & $1(100.0)$ & $0(0.0)$ & $0(0.0)$ & $0(0.0)$ & $1(100.0)$ & $0(0.0)$ & $0(0.0)$ \\
\hline \multicolumn{9}{|c|}{ Duration of residence } \\
\hline$\geq 10$ years & $0(0.0)$ & $65(90.3)$ & $7(9.7)$ & $0(0.0)$ & $0(0.0)$ & 70 (97.2) & $2(2.8)$ & $0(0.0)$ \\
\hline$<10$ years & $4(14.3)$ & $23(82.1)$ & $1(3.6)$ & $0(0.0)$ & $6(21.4)$ & $22(78.6)$ & $0(0.0)$ & $0(0.0)$ \\
\hline
\end{tabular}

Table 3 Association between duration of residence and severity of maxillar and mandibular gingival pigmentation among Nuha residents

\begin{tabular}{|c|c|c|c|c|c|c|c|c|}
\hline \multirow[b]{4}{*}{ Duration of Residence } & \multicolumn{8}{|c|}{ Gingival Pigmentation (DOPI value) } \\
\hline & \multicolumn{4}{|c|}{ Maxillar } & \multicolumn{4}{|c|}{ Mandibular } \\
\hline & None & Mild & None & Mild & None & Mild & None & Mild \\
\hline & n (\%) & n (\%) & n (\%) & n (\%) & n (\%) & n (\%) & n (\%) & n (\%) \\
\hline$\geq 10$ years & $0(0.0)$ & $65(90.3)$ & $7(9.7)$ & $0(0.0)$ & $0(0.0)$ & $70(97.2)$ & $2(2.8)$ & $0(0.0)$ \\
\hline$<10$ years & $4(14.3)$ & $23(82.1)$ & $1(3.6)$ & $0(0.0)$ & $6(21.4)$ & $22(78.6)$ & $0(0.0)$ & $0(0.0)$ \\
\hline$p$ value & \multicolumn{4}{|c|}{$0.003^{*}$} & \multicolumn{4}{|c|}{$0.000^{*}$} \\
\hline
\end{tabular}

"Chi-square test, $p<0.05$ significance

In the 65 years and older group, there was only 1 patient and this subject had mild pigmentation on both the maxilla and mandible.

In the duration of residence groups, subjects that had been living in Nuha District for at least 10 years, all (72 subjects) had gingival pigmentation and it was mostly mild: 65 (90.3\%) had mild maxillar pigmentation and $70(97.2 \%)$ had mild mandibular pigmentation.

Meanwhile, among subjects that had been living in Nuha District for less than 10 years, 4 out of 28 subjects (14.3\%) had normal gingival color in their maxilla and 6 out of 28 subjects (21.4\%) had normal gingival color in their mandible. Of subjects that had been living in Nuha District for less than 10 years and had gingival pigmentation, mostly were of mild severity, with $23(82.1 \%)$ on the maxilla and $22(78.6 \%)$ on the mandible.

Table 3 shows the significant association of duration of residence and severity of maxillar and mandibular gingival pigmentation among Nuha residents.

\section{Discussion}

The present study was conducted to determine the association between duration of residence and severity if gingival pigmentation. This association can be translated as duration of exposure among Nuha District residents and may show accumulative effect of the exposure over the time.

Based on the results, there was significant association between duration of residence and severity of gingival pigmentation among Nuha District residents. The average DOPI value for people that has been living at least 10 years in the area was significantly higher than of those living for less than 10 years.

The concentration of heavy metal in the meat from animals raised in this district depends on 
source of their food and their level of heavy metal exposure. In that study, the concentration of heavy metal in the meat was not above safety limit but other factors such as amount and frequency of feeding needs to be taken into account because of the accumulation effect. ${ }^{6}$ In another study by Oktaria et al. ${ }^{12}$ duration of occupation as traffic police officers did have significant effect on the severity of heavy metalexposure as they found that gingival lead line was significantly more severe among police officers that had been on traffic duty for longer time. ${ }^{12}$ These studies corroborates with our result that accumulative effect may present significantly in heavy metalexposure from the water, air and/or land.

In our study, we analyzed the severity of gingival pigmentation among several age groups. Although it has been studied that gingival pigmentation may becomes more apparent as a person becomes older ${ }^{13}$ our study did not show the similar result. This difference can be explained as in this study, older age does not necessarily mean longer duration of residence in Nuha District since people might have been migrating in and out of the area prior to the study.

\section{Conclusion}

Duration of residence in a Nuha District, Luwu Timur Regency, South Sulawesi shows significant association with severity of gingival pigmentation among the residents. Such duration that represents the duration of exposure and accumulated amount of exposure. Further studies, e.g. blood level examination and biochemical tests are required to deepen our understanding on the dynamic interaction among the health of people and their environment especially in previously mined lands such as the Nuha District of Luwu Timur Regency, South Sulawesi.

\section{Conflict of Interest}

The authors report no conflict of interest.

\section{References}

1. Peeran SW, Ramalingam K, Peeran SY, et al. Gingival pigmentation index proposal of a new index with a brief review of current indices. Eur J Dent 2014;8: 287-290.

2. Dummett CO, Gupta OMP. Estimating the epidemiology of oral pigmentation. J Natl Med Assoc 1964;56: 419-420

3. Hasan S, Khan NI, Sherwani OAK, et al. Drugs causing orofacial pigmentation: an overview of literature. Int Res J Pharm 2013;4: 40-43.

4. Kauzman A, Pavone M, Blanas N, Bradley G. Pigmented lesions of the oral cavity: review, differential diagnosis, and case presentations. J Can Dent Assoc 2004;70: 682-683.

5. Dilea M, Prelipcean DD, Ioni D. About oral health of romanian children from various polluted area due to heavy metals. UPB Sci Bull 2012;74: 171-182.

6. El-Said KF, El-Ghamry AM, Mahdy NH, El-Bestawy NA. Chronic occupational exposure to lead and its impact on oral health. J Egypt Public Health Assoc 2008;83: 451-466.

7. Profil kecamatan Nuha. 2012 [Cited: 2014 November 30]; Available from : http://www.luwutimurkab.go.id/ lutim/index.php?option=com_content\&view=arti cle\&id=428\&Itemid $=302$

8. Purnama A, Zakaria F, Kusumaningrum HD, Hasan S. Selected minerals in meat of cattle grazing in mine revegetation areas and safe consumption for human. Food science and quality management 2014; 30: 18-25

9. Setiadhi R, Soewondo W. Hubungan antara pigmentasi melanin pada Gingiva anak-anak dengan riwayat orang tua perokok di Rumah Sakit Gigi dan Mulut Fakultas Kedokteran Gigi Universitas Padjadjaran. New Bionatura 2011;13: 31-39.

10. Penyakit gingiva. Universitas Gadjah Mada. [cited: 2014 November 30]; Available from: http:// www.google.com/url? sa =t\&rct=j\&q=\&esrc=s \& source $=$ we b \& $c d=5 \& c$ ad $=r j a \& u$ a ct $=8 \& v e d=-$ 0CEEQFjAE\&url=http \% 3 A \% 2F\%2 Felisa.ugm. ac.id\%2Fuser\%2Farchive\%2Fdownload\%2F51185\%2F63ad3661c2d816bb3861f74ea1772816\&ei=gcRVVKaXIszguQTFkYKAAg\&usg=AFQjCNFP3pY3hq2fpx7pB0V8KGjEqvjRYQ\&bvm=bv.78677474,d.c2E

11. Petersen PE, Gormen C. Oral conditions among German battery factory workers. Community Dent Oral Epidemiol 1991;19: 104-106.

12. Oktaria C, Munandar S. Pengaruh masa kerja terhadap kejadian Gingival lead line pada polisi lalu lintas di kota Semarang. Dental Health Department Medical Faculty Diponegoro University 2009. p. 1-35.

13. Ghapanchi J, Darvishi M, Derafshi R, et al. Prevalence of Oral pigmented lesions: a prospective study. Aust J Basic \& Appl Sci 2012;6: 417-420.

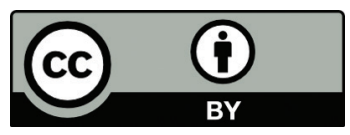

This work is licensed under a Creative Commons Attribution 